\title{
Effect of Square Planting and Nitrogen Scheduling on Yield and Micrometeorological Parameters in Maize
}

\author{
Dharmalingam Selvakumar $^{1}$, Kumaran Velayudham ${ }^{2} \&$ Nallasamy Thavaprakaash ${ }^{3}$ \\ 1 e-Extension Centre, Tamil Nadu Agricultural University, Coimbatore, Tamil Nadu, India \\ ${ }^{2}$ Agricultural College and Research Institute, Tamil Nadu Agricultural University, Madurai, Tamil Nadu, India \\ ${ }^{3}$ Krishi Vigyan Kendra, Tamil Nadu Agricultural University, Thirupathisaram, Tamil Nadu, India \\ Correspondence: Dharmalingam Selvakumar, e-Extension Centre, Tamil Nadu Agricultural University, \\ Coimbatore, Tamil Nadu 641003, India. Tel: 91-75983-79982. E-mail: selva6755@gmail.com
}

Received: December 2, 2015 Accepted: December 29, 2015 Online Published: January 15, 2016

doi:10.5539/jas.v8n2p141 URL: http://dx.doi.org/10.5539/jas.v8n2p141

\begin{abstract}
Altering plant spatial distribution induces changes in micro-meteorology of crop canopy and have cumulative effect on yield. Creation of suitable plant spatial distribution is indispensable to explore the beneficial effects of spatial pattern and it could be possible only through altering rectangular spatial distribution, which is commonly practiced in maize. Most of the nitrogen $(\mathrm{N})$ scheduling approaches are growth stages based without considering crop demand and soil fertility status which may not yield better, warrants need based $\mathrm{N}$ management for better production in maize. The present study has investigated effects of spatial pattern and nitrogen scheduling on intercepted photosynthetically active radiation (IPAR), light extinction co-efficient (' $k$ '), leaf temperature (LT) and productivity of maize. The experiments were conducted during 2011 and 2012 at Tamil Nadu Agricultural University, Coimbatore. Treatments were laid out in split-plot design and replicated thrice. Treatments were: six levels of spatial pattern $(60 \times 25,30 \times 30,35 \times 35,40 \times 40,45 \times 45$ and $50 \times 50 \mathrm{~cm})$. Growth stage based and need based approach of leaf color chart based (LCC) nitrogen scheduling were imposed. Field experimental results indicated that maize canopy under $30 \times 30$ and $35 \times 35 \mathrm{~cm}$ spatial pattern intercepted 10 to $15 \%$ more light compared to rectangular pattern $(60 \times 25 \mathrm{~cm})$. The ' $\mathrm{k}$ ' value and leaf temperature were reduced under this pattern. Higher maize grain yield (GY) was recorded at $35 \times 35 \mathrm{~cm}$ spatial distribution. The LCC based N scheduling recorded higher values of IPAR, LT and lower ' $\mathrm{k}$ ' values. Square planting favored canopy micro-meterological parameters and which in turn enhanced grain yield of maize.
\end{abstract}

Keywords: leaf color chart, maize, nitrogen scheduling, square planting, yield

\section{Introduction}

Plant spatial pattern is an important agronomic practice which is related to light interception and the plants are able to convert light energy into chemical energy, which is pre-requisite for $\mathrm{CO}_{2}$ fixation. Also, it alters photosphere and rhizosphere exploitation by the plants especially when spacing is inadequate and the plants suffer clustering together. In general, maize plant is typically grown at a wider inter row spacing than intra row spacing. This would create a heterogeneous environment in which the plants receive higher red light to far-red light from the inter row spaces (Maddonni et al., 2002). Several studies considered maize canopy as homogeneous medium with random leaf orientation distribution. Maddonni et al. (2001a) have detected that maize leaf orientation could react to filling empty spaces (e.g., intra or inter-row) due to plant spatial arrangement. Acciaresi and Zuluaga (2006) reported that in clay loamy soils, the grain yield was 30 and 33 per cent higher under $35 \times 35 \mathrm{~cm}$ pattern over $70 \times 17.5 \mathrm{~cm}$, respectively. Fanadzo et al. (2010) indicated that closer square planting of $45 \times 38 \mathrm{~cm}$ recorded higher green cob yield and grain yield than rectangular pattern of $90 \times 19 \mathrm{~cm}$ at Eastern Cape, South Africa.

Nitrogen $(\mathrm{N})$ is one of the major plant nutrients without which the agricultural production is not possible. It is estimated that about 50 per cent of world's $\mathrm{N}$ fertilizer was applied to three cereal crops viz., wheat, maize and rice (Khosla et al., 2010). Effective management of fertilizer, particularly $\mathrm{N}$ is a major challenge for researchers and producers. To answer the questions of when, where and how much, we require a monitoring technique to evaluate the $\mathrm{N}$ status of crops. The LCC developed for rice would also suitable for maize as indicated by spectral reflectance measurements performed on rice and maize leaves (Witt et al., 2005). The LCC proves to be an effective tool in 
detecting the maize additional $\mathrm{N}$ need, giving higher yields and increased profit compared with fixed rates (Pasuquin et al., 2012).

Crosbie (1982) reported that light interception is primarily driven by intercepting plant surface, while light utilization is a function of canopy photosynthesis. Girardin and Tollenaar (1994) found that Intercepted photosynthetically active radiation (IPAR) was influenced by canopy architecture of crops i.e., function of shape, distribution and orientation of leaves. Corn under square pattern intercepted more PAR than rectangular pattern at flowering stage (Acciaresi \& Chidichimo, 2007). The light extinction co-efficient (' $k$ ') is a measure of interaction between canopy architecture and its orientation on the efficiency of radiation intercepted per unit leaf area index (Maddonni et al., 2001b). Drouet and Kiniry (2008) reported that ' $\mathrm{k}$ ' value increased when the row spacing increased from $0.32 \mathrm{~m}$ (square plant rearrangement) to $0.50 \mathrm{~m}$. Canopy temperature depression is used as a potential indirect criterion for yield (Rashid et al., 1999). The leaf appearance rate was lower at higher plant densities because of shading (Bos et al., 2000). Maize is mostly grown under rectangular pattern without considering availability of abundant light sources. It is a nitro-positive crop and most of the nitrogen scheduling approaches are either growth stage based or fixed time method is practiced. Hence, this study has been contemplated to study the various square planting pattern and $\mathrm{N}$ scheduling approaches effects on micro-meteorological parameters and economic yield.

Globally, little attempt has been made to assess the changes in micro-meteorological parameters of the canopy due to alteration of rectangular spatial distribution in to square pattern. Similarly, the research on LCC based N scheduling in maize was very scanty. Hence, the changes in micro-meteorological environment and productivity under various plant spatial distribution and nitrogen scheduling approaches have been considered as main objective for this field study.

\section{Methods}

\subsection{Seasons and Weather Data}

Field experiments were conducted at the Department of Agronomy, Agricultural College and Research Institute, Coimbatore during winter season of 2011 and 2012. The region is characterized as semi-arid tropical (SAT) climate, located at $11^{\circ} 8^{\prime} \mathrm{N}$ latitude and $77^{\circ} 8^{\prime} \mathrm{E}$ longitude. The mean annual rainfall (52 years) at Coimbatore is 713 $\mathrm{mm}$ distributed over about 47 rainy days with a $30 \%$ annual coefficient of variation. The rainfall is monsoon type, with a south-west monsoon from June to September and a north-east monsoon from October to December. The annual mean (1981-2012) maximum and minimum temperatures are $31.58^{\circ} \mathrm{C}$ and $21.28^{\circ} \mathrm{C}$, respectively.

The pre-sowing composite soil samples were collected from the experimental soil was analyzed for physical-chemical characteristics. The experimental soil was sandy clay loam in texture with 1.32 and $1.30 \mathrm{~g} \mathrm{cc}^{-1}$ of bulk density and particle density of 2.24-2.26 $\mathrm{g} \mathrm{cc}^{-1}$ and porosity of $41.07-40.05 \%$ during 2011 and 2012, respectively. The nutrient status was low (216-205 $\left.\mathrm{kg} \mathrm{ha}^{-1}\right)$, medium (15.2-16.3 $\left.\mathrm{kg} \mathrm{ha}^{-1}\right)$ and high (550-515 $\left.\mathrm{kg} \mathrm{ha}^{-1}\right)$ for available nitrogen $(\mathrm{N})$, phosphorus $(\mathrm{P})$ and potassium $(\mathrm{K})$, respectively.

\subsection{Layout and Experimentation}

The experiment was laid out in a split plot design and the treatments were replicated thrice. Main plot treatments comprised of five levels of square plant spacing with recommended rectangular crop geometry for comparison. Three nitrogen scheduling treatments were assigned to sub plots where need based nitrogen scheduling was compared with conventional scheduling approaches (Table 1). Single cross maize hybrid NK 6240, released from Syngenta seeds (Pvt.) Ltd., was used for the experimental study. The standardized new four panel LCC developed by IRRI, Philippines in collaboration with University of California Co-operative Extension was used (Witt et al., 2005) to measure the leaf color intensity. The LCC values were recorded at middle lamina of the third fully expanded leaf from the top of maize at weekly interval from 21 DAS to 72 DAS. 
Table 1. Treatment details

\begin{tabular}{|c|c|c|}
\hline \multicolumn{3}{|c|}{ Main plot: Spatial pattern (cm) } \\
\hline & - & $60 \times 25$ \\
\hline & - & $30 \times 30$ \\
\hline & - & $35 \times 35$ \\
\hline & - & $40 \times 40$ \\
\hline & - & $45 \times 45$ \\
\hline & - & $50 \times 50$ \\
\hline \multicolumn{3}{|c|}{ Sub plot: Nitrogen scheduling } \\
\hline & - & $\begin{array}{l}\text { Recommended dose of nitrogen (RDN) at } 150 \mathrm{~kg} \mathrm{ha}^{-1} \text { in } 3 \text { splits as } 25,50 \text { and } 25 \text { per cent at basal, } \\
25 \text { and } 45 \text { DAS, respectively }\end{array}$ \\
\hline $\mathrm{N}_{2}$ & - & RDN at $150 \mathrm{~kg} \mathrm{ha}^{-1}$ in 4 splits each 25 per cent at basal, 15,30 and 45 DAS \\
\hline & - & $\begin{array}{l}\text { Leaf color chart (LCC) based nitrogen scheduling (whenever LCC critical value falls below } 5 \text {, top } \\
\text { dressing of } \mathrm{N} \text { at } 30 \mathrm{~kg} \mathrm{ha}^{-1} \text { ) }\end{array}$ \\
\hline
\end{tabular}

\subsection{Observations}

Measurement of photosynthetic active radiation (PAR) was obtained by using a line quantum sensor (LI-COR model LI-185A). It measures incident photosynthetic photon flux density (PPFD) received above and beneath the crop canopy. All the components of PAR are expressed as percentage of incident radiation at 30,60 and 90 DAS. The values were expressed as ( $\mu$ mol (photons) $\mathrm{m}^{-2} \mathrm{~s}^{-1}$ ). The percentage of light intercepted by the crop canopy (IPAR) was calculated by using the formula adopted by Biggs (1979).

$$
I P A R=\frac{(P A R)^{T C}-(P A R)^{H}}{(P A R)^{T C}} \times 100
$$

Where,

$(\mathrm{PAR})^{\mathrm{TC}}$ : PAR at top of the canopy, and;

$(\mathrm{PAR})^{\mathrm{H}}$ : PAR at desired height of the canopy.

Light extinction co-efficient ('k') value was worked out by using the formula adopted by Monsi and Saeki (1953).

$$
\mathrm{I}=\mathrm{I}_{\mathrm{o}} \exp ^{(-\mathrm{kf})}
$$

Where,

$\mathrm{k}: \mathrm{I} / \mathrm{L} \log _{\mathrm{e}}\left(\mathrm{I} / \mathrm{I}_{\mathrm{o}}\right)$;

f: Light flux density to a horizontal surface below L units of LAI;

I: Light flux density below the canopy;

$\mathrm{I}_{\mathrm{o}}$ : Light flux density above the canopy;

E: The base to the natural logarithms, and

' $\mathrm{k}$ ': Extinction co-efficient.

The temperature of the leaf was measured on hot sunny day by the method of Blad and Rosenberg (1976) using hand held Infrared thermometer with laser marker (Raytek Corp., Model RAYST3U, Santa Cruz, CA Model) and the mean values were expressed in ${ }^{\circ} \mathrm{C}$. Harvested matured cobs from net plot after physiological maturity were dried, threshed, weighed and calculated as kilogram per plot and expressed in kilogram per hectare.

\subsection{Data Analysis}

The data pertained to yield and micrometeorological parameters were subjected to statistical analysis by Analysis of Variance (ANOVA) using AGRES (Data Entry Module for AgRes Statistical software version 3.01, 1994 Pascal Intl. Software Solutions). Differences between means were evaluated for significance using Least Significant Difference (LSD) at 5\% probability level as suggested by K. A. Gomez and A. A. Gomez (2010).

\section{Results}

\subsection{Grain Yield}

The maize grain yield was significantly influenced by the spatial distribution and nitrogen scheduling practices 
during 2011 and 2012 (Table 2). Square spatial distribution of maize at $35 \times 35 \mathrm{~cm}\left(\mathrm{M}_{3}\right)$ resulted higher maize grain yield (10.3 and $10.0 \mathrm{t} \mathrm{ha}^{-1}$ during 2011 and 2012, respectively) which was at par $\mathrm{M}_{1}$ and was superior over other treatments. Altering planting pattern from rectangular $\left(\mathrm{M}_{1}\right)$ to square with almost similar planting density of around 8 plants $\mathrm{m}^{-2}\left(\mathrm{M}_{3}\right)$ contributed 343 and $400 \mathrm{~kg}$ increased grain yield ha ${ }^{-1}$ during 2011 and 2012, respectively. Plants planted at wider distance $\left(\mathrm{M}_{5}\right.$ and $\left.\mathrm{M}_{6}\right)$ recorded significantly lower yields than other treatments and the least yields (6.4 and $7.2 \mathrm{t} \mathrm{ha}^{-1}$ during 2011 and 2012, respectively) were recorded under $\mathrm{M}_{6}$. Reduction in yield was observed more in $\mathrm{M}_{6}$ when compared to other treatments. However, maize yield obtained under $\mathrm{M}_{2}$ was comparable with $\mathrm{M}_{4}$.

Table 2. Effect of spatial pattern and nitrogen scheduling on maize grain yield

\begin{tabular}{|c|c|c|c|c|c|c|c|c|}
\hline \multirow{2}{*}{ Treatments } & \multicolumn{4}{|c|}{2011} & \multicolumn{4}{|c|}{2012} \\
\hline & $\mathbf{N}_{1}$ & $\mathbf{N}_{2}$ & $\mathbf{N}_{3}$ & Mean & $\mathbf{N}_{1}$ & $\mathbf{N}_{2}$ & $\mathbf{N}_{3}$ & Mean \\
\hline \multicolumn{9}{|c|}{ Spatial pattern $(\mathrm{cm})$} \\
\hline$M_{1}-60 \times 25$ & 9.3 & 9.9 & 10.8 & 10.0 & 9.0 & 8.8 & 11.0 & 9.6 \\
\hline $\mathrm{M}_{2}-30 \times 30$ & 7.5 & 9.0 & 8.8 & 8.5 & 7.9 & 7.8 & 8.4 & 8.0 \\
\hline $\mathrm{M}_{3}-35 \times 35$ & 9.5 & 10.2 & 11.3 & 10.3 & 8.7 & 9.9 & 11.6 & 10.0 \\
\hline $\mathrm{M}_{4}-40 \times 40$ & 7.9 & 8.5 & 9.5 & 8.6 & 7.2 & 8.3 & 9.4 & 8.3 \\
\hline$M_{5}-45 \times 45$ & 7.8 & 6.6 & 7.9 & 7.4 & 7.4 & 7.4 & 8.1 & 7.6 \\
\hline $\mathrm{M}_{6}-50 \times 50$ & 6.0 & 6.1 & 7.2 & 6.4 & 6.6 & 7.1 & 7.7 & 7.2 \\
\hline \multirow[t]{2}{*}{ Mean } & 8.0 & 8.4 & 9.3 & & 7.8 & 8.2 & 9.4 & \\
\hline & $\mathrm{M}$ & $\mathrm{N}$ & $\mathrm{M} \times \mathrm{N}$ & & $\mathrm{M}$ & $\mathrm{N}$ & $\mathrm{M} \times \mathrm{N}$ & \\
\hline SEd & 0.37 & 0.19 & 0.53 & & 0.46 & 0.20 & 0.61 & \\
\hline $\mathrm{CD}(\mathrm{P}<0.05)$ & 0.83 & 0.39 & 1.14 & & 1.02 & 0.42 & 1.33 & \\
\hline
\end{tabular}

Discernible variations have been observed due to $\mathrm{N}$ scheduling approaches during 2011 and 2012. Maize crop nourished through LCC based $\mathrm{N}$ application $\left(\mathrm{N}_{3}\right)$ produced significantly more grain yield $\left(9.3\right.$ and $9.4 \mathrm{tha}^{-1}$ during 2011 and 2012, respectively) than the other treatments. The increase was 1247 and $1580 \mathrm{~kg} \mathrm{ha}^{-1}$ during 2011 and 2012 , respectively in $\mathrm{N}_{3}$ when compared to existing practice $\left(\mathrm{N}_{1}\right)$. Drastic reduction in maize grain yield was obtained under recommended dose of nitrogen $(\mathrm{RDN})$ at $150 \mathrm{~kg} \mathrm{ha}^{-1}\left(\mathrm{~N}_{1}\right)$ and recorded the lowest $(8.0$ and $7.8 \mathrm{~kg}$ $\mathrm{ha}^{-1} 2011$ and 2012, respectively) grain yield than other treatments. However, difference between $\mathrm{N}_{1}$ and $\mathrm{N}_{2}$ were non significant.

Maize grain yield was highly influenced by plant spatial distribution and $\mathrm{N}$ scheduling approaches together. The combination of LCC based N management and maize planted at $35 \times 35 \mathrm{~cm}\left(\mathrm{M}_{3} \mathrm{~N}_{3}\right)$ was found to record higher grain yields (11.3 and $11.6 \mathrm{tha}^{-1}$ during 2011 and 2012, respectively) and the same was statistically comparable with $\mathrm{M}_{1} \mathrm{~N}_{3}$. Widely planted maize with RDN at $150 \mathrm{~kg} \mathrm{ha}^{-1}$ registered significantly lower yield (6024 and 6628 during 2011 and 2012, respectively) compared to others.

\subsection{Intercepted Photosynthetically Active Radiation (IPAR)}

Varied plant spatial distribution had significant effect on observed IPAR values and registered relatively similar values during both the years. Plant spatial distribution treatments registered lower values during the vegetative stage of growth (30 DAS) and comparatively more during blooming and cob formation (60 and 90 DAS) stages (Table 3).

During 30 DAS, IPAR of maize canopy was higher (50.4 and 50.7\% during 2011 and 2012, respectively) under closer square spatial distribution $\left(\mathrm{M}_{2}\right)$ and it was on par with moderately wider planted square pattern $\left(\mathrm{M}_{3}\right)$ and significantly differed from widely planted square patterns $\left(\mathrm{M}_{4}, \mathrm{M}_{5}\right.$ and $\left.\mathrm{M}_{6}\right)$ and also rectangular planting pattern $\left(\mathrm{M}_{1}\right)$. Similar trend was observed during 60 and 90 DAS stages of maize. Both spatial distributions $\left(\mathrm{M}_{2}\right.$ and $\left.\mathrm{M}_{3}\right)$ intercepted 15 to $16 \%$ more light at 30 DAS and the variation was 4 to $10 \%$ at 60 DAS when compared to rectangular spatial distribution $\left(\mathrm{M}_{1}\right)$. As the square pattern widened from $35 \mathrm{~cm}$ to $50 \mathrm{~cm}$, resulted reduction in IPAR and lowest values (29.9, 77.4 and $79.2 \%$ at 30, 60 and 90 DAS, respectively during 2011) were observed under $\mathrm{M}_{5}$. The similar trend was observed during 2012 too, except at 60 and 90 DAS wherein $\mathrm{M}_{6}$ registered the lowest IPAR. 
Table 3. Effect of spatial pattern and nitrogen scheduling on Intercepted photosynthetically active radiation (\%) at various growth stages of maize

\begin{tabular}{|c|c|c|c|c|c|c|}
\hline \multirow{2}{*}{ Treatments } & \multicolumn{3}{|c|}{2011} & \multicolumn{3}{|c|}{2012} \\
\hline & 30 DAS & 60 DAS & 90 DAS & 30 DAS & 60 DAS & 90 DAS \\
\hline \multicolumn{7}{|c|}{ Spatial pattern $(\mathrm{cm})$} \\
\hline$M_{1}-60 \times 25$ & 34.8 & 84.8 & 86.0 & 35.1 & 84.7 & 84.9 \\
\hline $\mathrm{M}_{2}-30 \times 30$ & 50.4 & 90.2 & 90.8 & 50.7 & 94.7 & 94.5 \\
\hline$M_{3}-35 \times 35$ & 49.5 & 88.7 & 89.5 & 49.6 & 89.1 & 89.6 \\
\hline$M_{4}-40 \times 40$ & 37.1 & 83.4 & 85.0 & 37.0 & 84.8 & 85.4 \\
\hline $\mathrm{M}_{5}-45 \times 45$ & 29.9 & 77.4 & 79.2 & 30.2 & 82.6 & 83.2 \\
\hline $\mathrm{M}_{6}-50 \times 50$ & 34.4 & 78.5 & 79.8 & 34.4 & 75.7 & 76.3 \\
\hline SEd & 2.5 & 2.6 & 2.3 & 3.5 & 1.7 & 1.8 \\
\hline $\mathrm{CD}(\mathrm{P}<0.05)$ & 5.6 & 5.9 & 5.1 & 7.9 & 3.8 & 3.9 \\
\hline \multicolumn{7}{|c|}{ Nitrogen scheduling } \\
\hline $\mathrm{N}_{1}$ & 39.1 & 83.0 & 83.9 & 39.3 & 85.7 & 86.0 \\
\hline $\mathrm{N}_{2}$ & 40.0 & 83.1 & 84.2 & 39.5 & 84.0 & 84.3 \\
\hline $\mathrm{N}_{3}$ & 38.9 & 85.4 & 87.0 & 39.8 & 86.2 & 86.7 \\
\hline SEd & 1.5 & 1.5 & 1.4 & 0.7 & 1.2 & 1.1 \\
\hline $\mathrm{CD}(\mathrm{P}<0.05)$ & NS & NS & NS & NS & NS & NS \\
\hline Interaction & NS & NS & NS & NS & NS & NS \\
\hline
\end{tabular}

Note. DAS: Days after sowing.

\subsection{Light Extinction Co-Efficient (' $k$ ')}

The ' $k$ ' value was low in early stage (30 DAS) and it doubled as advancement of crop growth (60 DAS) and showed mild increase towards maturity stage (90 DAS). Different spatial pattern significantly influenced the ' $\mathrm{k}$ ' value of maize (Table 4).

Table 4. Effect of spatial pattern and nitrogen scheduling on Light extinction co-efficient (' $k$ ') at various growth stages of maize

\begin{tabular}{|c|c|c|c|c|c|c|}
\hline \multirow{2}{*}{ Treatments } & \multicolumn{3}{|c|}{2011} & \multicolumn{3}{|c|}{2012} \\
\hline & 30 DAS & 60 DAS & 90 DAS & 30 DAS & 60 DAS & 90 DAS \\
\hline \multicolumn{7}{|c|}{ Spatial pattern $(\mathrm{cm})$} \\
\hline$M_{1}-60 \times 25$ & 0.251 & 0.537 & 0.613 & 0.203 & 0.439 & 0.508 \\
\hline $\mathrm{M}_{2}-30 \times 30$ & 0.292 & 0.437 & 0.569 & 0.211 & 0.523 & 0.624 \\
\hline$M_{3}-35 \times 35$ & 0.301 & 0.498 & 0.592 & 0.284 & 0.504 & 0.633 \\
\hline $\mathrm{M}_{4}-40 \times 40$ & 0.251 & 0.501 & 0.597 & 0.224 & 0.537 & 0.589 \\
\hline$M_{5}-45 \times 45$ & 0.250 & 0.508 & 0.573 & 0.221 & 0.538 & 0.639 \\
\hline $\mathrm{M}_{6}-50 \times 50$ & 0.302 & 0.568 & 0.606 & 0.299 & 0.557 & 0.633 \\
\hline SEd & 0.018 & 0.033 & 0.054 & 0.021 & 0.030 & 0.041 \\
\hline $\mathrm{CD}(\mathrm{P}<0.05)$ & 0.039 & 0.075 & NS & 0.046 & 0.066 & NS \\
\hline \multicolumn{7}{|c|}{ Nitrogen scheduling } \\
\hline $\mathrm{N}_{1}$ & 0.269 & 0.527 & 0.603 & 0.233 & 0.532 & 0.608 \\
\hline $\mathrm{N}_{2}$ & 0.277 & 0.489 & 0.589 & 0.241 & 0.515 & 0.599 \\
\hline $\mathrm{N}_{3}$ & 0.277 & 0.508 & 0.582 & 0.248 & 0.502 & 0.606 \\
\hline SEd & 0.014 & 0.021 & 0.033 & 0.013 & 0.024 & 0.024 \\
\hline $\mathrm{CD}(\mathrm{P}<0.05)$ & NS & NS & NS & NS & NS & NS \\
\hline Interaction & NS & NS & NS & NS & NS & NS \\
\hline
\end{tabular}

Note. DAS: Days after sowing. 
Among different spatial distribution evaluated, spatial pattern of $50 \times 50 \mathrm{~cm}\left(\mathrm{M}_{6}\right)$ registered higher ' $\mathrm{k}$ ' values $(0.302$ and 0.568 at 30 and 60 DAS, respectively during 2011$)$ and it was on par with $35 \times 35 \mathrm{~cm}\left(\mathrm{M}_{3}\right)$ and $30 \times 30$ $\mathrm{cm}\left(\mathrm{M}_{2}\right)$ at 30 DAS, but, it was on par with all other treatments except $\mathrm{M}_{2}$ at 60 DAS. The lowest ' $\mathrm{k}$ ' value $(0.250)$ at 30 DAS was observed with $\mathrm{M}_{5}$. As crop age advanced, the lowest ' $\mathrm{k}$ ' (0.437) was registered under $\mathrm{M}_{2}$ during 2011. Similarly, during 2012, wider spatial distribution $\mathrm{M}_{6}$ recorded significantly higher ' $\mathrm{k}$ ' value $(0.299$ and 0.557 at 30 and 60 DAS, respectively) and it was comparable with $\mathrm{M}_{3}$ at 30 DAS. However, it was on par with all other treatments except $\mathrm{M}_{1}$ at 60 DAS. Rectangular spatial distribution $\left(\mathrm{M}_{1}\right)$ registered the lowest ' $\mathrm{k}$ ' values $(0.203$ and 0.439 at 30 and $60 \mathrm{DAS}$, respectively during 2012) compared to other treatments. The spatial distributions had no significant effect on ' $\mathrm{k}$ ' value at 90 DAS during both the years.

\subsection{Leaf Temperature}

The growth of the canopy leads to slight increase in leaf temperature $\left({ }^{\circ} \mathrm{C}\right)$ and it was significantly influenced by the both spatial pattern and nitrogen scheduling treatments (Table 5). During 2011, among different spatial distribution treatments, maize planted at $45 \times 45 \mathrm{~cm}\left(\mathrm{M}_{5}\right)$ recorded higher leaf temperature $\left(30.3\right.$ and $30.5{ }^{\circ} \mathrm{C}$, respectively) on 30 and 60 DAS over rest of the treatments. It was on par with $50 \times 50 \mathrm{~cm}\left(\mathrm{M}_{6}\right)$ and $40 \times 40 \mathrm{~cm}\left(\mathrm{M}_{4}\right)$ at 30 DAS, but at 60 DAS, it was at par with all other treatments except $\mathrm{M}_{1}(60 \times 25 \mathrm{~cm})$ during 2011. At 90 DAS, spatial distribution of $35 \times 35 \mathrm{~cm}\left(\mathrm{M}_{3}\right)$ reached higher leaf temperature $\left(30.8{ }^{\circ} \mathrm{C}\right)$ and it was comparable with all other treatments except $\mathrm{M}_{1}$. Rectangular spatial distribution $\left(\mathrm{M}_{1}\right)$ registered the lowest leaf temperature (28.0, 28.5 and $29.4{ }^{\circ} \mathrm{C}$ at 30, 60 and 90 DAS, respectively during 2011). Similarly, during 2012, $\mathrm{M}_{5}$ registered more leaf temperature (29.3, 29.9 and $30.3{ }^{\circ} \mathrm{C}$ at 30,60 and 90 DAS, respectively). However, the least leaf temperature values ( 28.6 and $28.4{ }^{\circ} \mathrm{C}$ ) were observed with $\mathrm{M}_{2}$ at 30 and $60 \mathrm{DAS}$, respectively during 2012.

Effect of $\mathrm{N}$ scheduling practices on leaf temperature was found to significant during both the years of study. Among $\mathrm{N}$ scheduling approaches, LCC based $\mathrm{N}$ application $\left(\mathrm{N}_{3}\right)$ recorded significantly higher leaf temperature (29.6, 30.3 and $30.8{ }^{\circ} \mathrm{C}$ at 30,60 and 90 DAS, respectively during 2011) compared to conventional $\mathrm{N}$ scheduling approaches $\left(\mathrm{N}_{2}\right.$ and $\left.\mathrm{N}_{1}\right)$. Similarly, during 2012 also, $\mathrm{N}_{3}$ treatment registered higher leaf temperature. Application of RDN at $150 \mathrm{~kg} \mathrm{ha}^{-1}$ in 3 splits $\left(\mathrm{N}_{1}\right)$ registered the lowest leaf temperature values $\left(29.2,29.4\right.$ and $29.6{ }^{\circ} \mathrm{C}$ at 30,60 and 90 DAS, respectively during 2011). The similar trend observed during 2012 also.

Table 5. Effect of spatial pattern and nitrogen scheduling on leaf temperature $\left({ }^{\circ} \mathrm{C}\right)$ at various stages of maize

\begin{tabular}{|c|c|c|c|c|c|c|}
\hline \multirow{2}{*}{ Treatments } & \multicolumn{3}{|c|}{2011} & \multicolumn{3}{|c|}{2012} \\
\hline & 30 DAS & 60 DAS & 90 DAS & 30 DAS & 60 DAS & 90 DAS \\
\hline \multicolumn{7}{|c|}{ Spatial pattern $(\mathrm{cm})$} \\
\hline$M_{1}-60 \times 25$ & 28.0 & 28.5 & 29.4 & 29.5 & 29.6 & 29.9 \\
\hline $\mathrm{M}_{2}-30 \times 30$ & 28.7 & 29.8 & 30.4 & 28.6 & 28.4 & 29.7 \\
\hline$M_{3}-35 \times 35$ & 28.8 & 30.1 & 30.8 & 28.8 & 28.8 & 29.1 \\
\hline $\mathrm{M}_{4}-40 \times 40$ & 29.5 & 30.2 & 30.1 & 29.3 & 29.3 & 29.6 \\
\hline$M_{5}-45 \times 45$ & 30.3 & 30.5 & 30.2 & 29.3 & 29.9 & 30.3 \\
\hline $\mathrm{M}_{6}-50 \times 50$ & 29.8 & 29.9 & 30.1 & 29.3 & 29.0 & 29.4 \\
\hline SEd & 0.4 & 0.5 & 0.3 & 0.3 & 0.3 & 0.4 \\
\hline $\mathrm{CD}(\mathrm{P}<0.05)$ & 1.0 & 1.1 & 0.8 & 0.6 & 0.8 & 0.9 \\
\hline \multicolumn{7}{|c|}{ Nitrogen scheduling } \\
\hline $\mathrm{N}_{1}$ & 29.2 & 29.4 & 29.6 & 29.0 & 28.9 & 29.0 \\
\hline $\mathrm{N}_{2}$ & 29.2 & 29.8 & 30.0 & 29.1 & 29.2 & 29.5 \\
\hline $\mathrm{N}_{3}$ & 29.6 & 30.3 & 30.8 & 29.3 & 29.5 & 30.0 \\
\hline SEd & 0.2 & 0.2 & 0.1 & 0.2 & 0.2 & 0.2 \\
\hline $\mathrm{CD}(\mathrm{P}<0.05)$ & 0.4 & 0.5 & 0.4 & 0.4 & 0.5 & 0.4 \\
\hline Interaction & NS & NS & NS & NS & NS & NS \\
\hline
\end{tabular}

Note. DAS: Days after sowing. 


\section{Discussion}

\subsection{Maize Grain Yield}

Plant spatial distribution had accumulated effect on canopy architecture and micro-meteorological parameters and finally reflected in crop yield. It was evidenced from the values recorded for critical micro-meteorological parameters viz., IPAR, light extinction co-efficient and leaf temperature of the crops. In general, maize grain yield during $2012(202.8 \mathrm{~mm})$ was slightly higher than in $2011(84.6 \mathrm{~mm})$ because of variability in seasonal rainfall. Singh (1997) opined that a well distributed rainfall throughout the life cycle with bright sunshine intermitted with rainfall is the most ideal condition for maize production.

Change in plant spatial distribution had significant effect on grain yield of maize. Present study showed substantial increment in yield was recorded under $35 \times 35 \mathrm{~cm}\left(\mathrm{M}_{3}\right)$ spatial distribution compared to others. The yield increase under $35 \times 35 \mathrm{~cm}\left(\mathrm{M}_{3}\right)$ ranged between 3.4 and $4.2 \%$ during 2011 and 2012, respectively when compared to the rectangular pattern of $60 \times 25 \mathrm{~cm}\left(\mathrm{M}_{1}\right)$ with similar density of 8 plants $\mathrm{m}^{-2}$. Drastic reduction in yield was noticed under wider spatial pattern of $50 \times 50 \mathrm{~cm}\left(\mathrm{M}_{6}\right)$ and it was 38 and $29 \%$ lesser than $\mathrm{M}_{3}$ during 2011 and 2012, respectively. The increment in grain yield under $\mathrm{M}_{3}$ when compared to $\mathrm{M}_{1}$ was due to less intra-plant competition for resources viz., space, water, light and nutrients. This less competition led to more uniform root and leaf distribution that promoted more effective interception of PAR (IPAR) and moderate density favored better utilization of intercepted light. Acciaresi and Zuluaga (2006) reported that the grain yields were 30 and 33 per cent higher under $35 \times 35 \mathrm{~cm}$ pattern over $70 \times 17.5 \mathrm{~cm}$, respectively. Fanadzo et al. (2010) also reported that closer square planting of $45 \times 38 \mathrm{~cm}$ recorded higher green cob yield and grain yield (33460 and $12547 \mathrm{~kg} \mathrm{ha}^{-1}$, respectively) than rectangular pattern of $90 \times 19 \mathrm{~cm}$ at eastern Cape, South Africa.

Nitrogen application at the right time and right amount is critical for plant health and environment (Islam et al., 2007). In our study also, LCC based $\mathrm{N}$ scheduling $\left(\mathrm{N}_{3}\right)$ strikingly increased the grain yield of maize. The percentage increase of $\mathrm{N}_{3}$ over $\mathrm{N}_{2}$ (RDN at $150 \mathrm{~kg} \mathrm{ha}^{-1}$ in 4 splits) was 10.3 and 14.1 and it was 15.6 and 20.3 per cent over $\mathrm{N}_{1}$ (RDN at $150 \mathrm{~kg} \mathrm{ha}^{-1}$ in 3 splits) during 2011 and 2012, respectively. The increased grain yield might be due to LCC based $\mathrm{N}$ application matched the maize crop $\mathrm{N}$ demand which led to increase in $\mathrm{N}$ uptake and improved the efficiency of applied $\mathrm{N}$. The LCC based $\mathrm{N}$ application received higher quantity of $\mathrm{N}$ up to $180 \mathrm{~kg} \mathrm{ha}^{-1}$ based on LCC threshold value. Under LCC based treatment, the threshold value 5 coincided with critical growth stages like $12^{\text {th }}$ leaf stage (28 DAS), $15^{\text {th }}$ leaf stage (35 DAS), $18^{\text {th }}$ leaf stage (42 DAS) tasseling (49 DAS) and silking (56 DAS) stages, respectively. The LCC based N application up to silking improved the vegetative and reproductive growth of maize and increased cob bearing plants. It is also noticed that late $\mathrm{N}$ application up to silking could provide an additional source for elevated rate of photosynthesis and transport of photo-assimilates during grain filling that resulted in the higher grain yield. Pasuquin et al. (2012) reported that adjusting N application according to leaf color (LCC cv. 4) resulted in $0.80 \mathrm{t} \mathrm{ha}^{-1}$ more grain yield in maize than fixed rates.

Grain yield was positively influenced by plant spatial distribution and $\mathrm{N}$ scheduling approaches together. Among different combinations evaluated, spatial distribution of $35 \times 35 \mathrm{~cm}$ and maize crop nourished with $\mathrm{N}$ based on LCC value $\left(\mathrm{M}_{3} \mathrm{~N}_{3}\right)$ produced higher grain yield than other combinations. The lowest yield was obtained under wider spacing of $50 \times 50 \mathrm{~cm}$ with RDN at $150 \mathrm{~kg} \mathrm{ha}^{-1}$ in 3 splits $\left(\mathrm{M}_{6} \mathrm{~N}_{1}\right)$. The reduction of grain yield up to 46.7 and $42.7 \%$ was observed under this treatment over $\mathrm{M}_{3} \mathrm{~N}_{3}$ and it also 21.7 and 28.7 per cent superior over $\mathrm{M}_{1} \mathrm{~N}_{1}(60 \times 25$ $\mathrm{cm}$ with RDN at $150 \mathrm{~kg} \mathrm{ha}^{-1}$ in 3 splits). The increased grain yield might be due to more $\mathrm{N}$ accumulation associated with radiation interception and increased volume of soil made available for exploration by each plant under square pattern than conventional spacing resulted in higher grain yield. This corroborates with the findings of (Blackmer et al., 1993; Biradar et al., 2012) in maize.

\subsection{Intercepted Photosynthetically Active Radiation (IPAR)}

Interception of incoming PAR in response to plant spatial distribution is widely reported and may play a role in interception and utilization of light. IPAR is primarily driven by intercepting plant surface, while light utilization is a function of canopy photosynthesis (Crosbie, 1982). The light interception was improved due to spatial pattern over the growth stages. Crop row spacing influences canopy architecture, which is a distinguishing characteristic that affects the utilization of light, water and nutrients.

The IPAR showed a steep increase from 30 to 60 DAS and maintained at 90 DAS. It was evident from the earlier findings that maize canopy growth at early stages was limited (Andrade et al., 2002) which caused less interception at initial stage irrespective of the treatments. In present study, both the square pattern of $30 \times 30 \mathrm{~cm}\left(\mathrm{M}_{2}\right)$ and $35 \times$ $35 \mathrm{~cm}\left(\mathrm{M}_{3}\right)$ intercepted maximum incoming photosynthetically active radiation (PAR) throughout the growth stages and it was more under $\mathrm{M}_{2}$ compared to rectangular spatial distribution of $60 \times 25 \mathrm{~cm}\left(\mathrm{M}_{1}\right)$ and other wider plant spatial treatments. This might be due to earlier canopy closure under square plant spatial distribution which 
enhanced light interception. Gotz and Bernhardt (2008) indicated that square planting covered surface area more favourably at the earliest stage, however, under normal sowing, maize plants overlap clearly frequent and the big space between the rows can only close very late. The increased LAI under closer spacing might have increased the IPAR. This also might be due to earlier canopy closure which enhanced light interception (Andrade et al., 2002). This result corroborates with the findings of (Bullock et al., 1988; Maddonni et al., 2006; Acciaresi \& Chidichimo, 2007) in maize. Wider spatial distribution in maize resulted lower radiation interception because maize did not show plasticity in leaf expansion which led to incomplete canopy closure and reduced ground cover (Andrade, 1995).

\subsection{Light Extinction Co-Efficient (' $k$ ')}

The light extinction co-efficient (' $k$ ') is a measure of interaction between canopy architecture and its orientation on the efficiency of radiation intercepted per unit leaf area index. The light extinction co-efficient within a row crop such as maize is influenced by canopy structure, which has to be defined in terms of the size, shape and orientation of shoot components (Maddonni et al., 2001b). The ' $\mathrm{k}$ ' values calculated from the observed parameters indicated that a significant increase at all the stages of crop growth whatever the spatial plant arrangement. This is in agreement with the results of Drouet and Kiniry (2008). In the present study, calculated ' $k$ ' value varied when the spatial distribution of $35 \times 35 \mathrm{~cm}\left(\mathrm{M}_{3}\right)$ increased to $50 \times 50 \mathrm{~cm}\left(\mathrm{M}_{6}\right)$, ' $\mathrm{k}$ ' value was also increased slightly. This result was consistent with experimental observations made by Drouet and Kiniry (2008) who reported that ' $k$ ' value increased when the row spacing increased from $0.32 \mathrm{~m}$ (square plant rearrangement) to $0.50 \mathrm{~m}$.

\subsection{Leaf Temperature}

Canopy temperature depression is used as a potential indirect criterion for yield (Rashid et al., 1999). The leaf appearance rate was lower at higher plant densities because of shade. This was not affected by small differences in canopy temperature, but, closely associated with reduction in the growth rate per individual plant (Bos et al., 2000). The findings on leaf temperature indicated that wider spatial pattern recorded higher temperatures compared to others. In the present study, most of the stages over the years, $M_{5}(45 \times 45 \mathrm{~cm})$ recorded higher leaf temperature. This is in accordance with the results of Bos et al. (2000). They observed that square planting with the density of 4.5 plants $\mathrm{m}^{-2}$ recorded higher leaf temperature. Rectangular spatial pattern of $60 \times 25 \mathrm{~cm}\left(\mathrm{M}_{1}\right)$ and closer square pattern of $30 \times 30 \mathrm{~cm}\left(\mathrm{M}_{2}\right)$ registered the lowest leaf temperature. The reduction of leaf temperature might be due to the effect of shading.

Nitrogen scheduling approaches resulted in significant variation on leaf temperature. Nitrogen application based on LCC value measured higher leaf temperature throughout growth stages. Girma et al. (2006) reported that canopy temperature was lower under more $\mathrm{N}$ fertilizer was applied and higher under less $\mathrm{N}$ applied treatment. The results obtained are on contrary with those results obtained by Girma et al. (2006). This was probably due to N scheduling treatments includes $\mathrm{N}$ fertilization at $180 \mathrm{~kg} \mathrm{ha}^{-1}$ based on LCC value $\left(\mathrm{N}_{3}\right)$ and $150 \mathrm{~kg} \mathrm{ha}^{-1}\left(\mathrm{~N}_{1}\right.$ and $\left.\mathrm{N}_{2}\right)$ and only moderate increase in $\mathrm{N}$ rate under LCC treatment might be the reason for slight variation in leaf temperature in our study.

Research findings of current study revealed that change in spatial pattern favored micro-meteorological parameters of maize canopy. Square pattern of $30 \times 30$ and $35 \times 35 \mathrm{~cm}$ recorded higher IPAR and it was intercepted 14 to $15 \%$ more light at early growth stage and 3 to $6 \%$ at later stage. The light extinction co-efficient $(' k$ ') value was lower in above planting pattern and it allows lesser amount of light to beneath ground surface and most of the light was intercepted by the canopy. Both planting pattern intercepted more light and maintaining optimum population under $35 \times 35 \mathrm{~cm}$ resulted higher economic yield. Square planting of $35 \times 35 \mathrm{~cm}$ and LCC based $\mathrm{N}$ scheduling can be adopted to sustain the maize production under diverse environment.

\section{References}

Acciaresi, H. A., \& Chidichimo, H. O. (2007). Spatial pattern effect on corn (Zea mays) weeds competition in the humid pampas of Argentina. Intl. J. Pest Manage., 53, 195-206. http://dx.doi.org/10.1080/09670870701288116

Acciaresi, H. A., \& Zuluaga, M. S. (2006). Effect of plant row spacing and herbicide use on weed above ground biomass and corn grain yield. Plan. Dan. Viçosa-MG., 24, 287-293. http://dx.doi.org/10.1590/S0100-83582006000200011

Andrade, F. H. (1995). Analysis of growth and yield of maize, sunflower and soybean grown at Balcarce, Argentina. Field Crops Res., 41, 1-12. http://dx.doi.org/10.1016/0378-4290(94)00107-N

Andrade, F. H., Calvino, P., Cirilo, A., \& Barbieri, P. (2002). Yield responses to narrow rows depend on increased radiation interception. Agron. J., 94, 975-980. http://dx.doi.org/10.2134/agronj2002.0975 
Biggs, W. W. (1979). Radiation measurement. LI-COR Publ. RMR2-1084. LI-COR, Lincoln, NE.

Biradar, D. P., Aladakatti, Y. R., Shivamurthy, D., Satyanarayana, T., \& Majumdar, K. (2012). Managing fertilizer nitrogen to optimize yield and economics of maize-wheat cropping system in northern Karnataka. Better Crops-South Asia, 6, 19-21.

Blackmer, T. M., Schepers, J. S., \& Vigil, M. F. (1993). Chlorophyll meter readings in corn as affected by plant spacing. Comm. Soil Sci. Plant Anal., 24, 2507-2516. http://dx.doi.org/10.1080/00103629309368971

Blad, B. L., \& Rosenberg, N. J. (1976). Measurement of crop temperature by thermocouple, infra-red thermometry and remotely sensed thermal imagery. Agron. J., 68, 635-641. http://dx.doi.org/10.2134/agronj1976.00021962006800040026x

Bos, H. J., Vos, J., \& Struik, P. C. (2000). Morphological analysis of plant density effects on early leaf area growth in maize. Nether. J. Agric. Sci., 48, 199-212. http://dx.doi.org/10.1016/s1573-5214(00)80014-7

Bullock, D. G., Nielsen, R. L., \& Nyquist, W. E. (1988). A growth analysis comparison of corn grown in $\begin{array}{llllll}\text { conventional and equidistant plant spacing. Crop Sci., 28, 254-258. } & \text {. }\end{array}$ http://dx.doi.org/10.2135/cropsci1988.0011183X002800020015x

Crosbie, T. M. (1982). Changes in physiological traits associated with long-term breeding efforts to improve grain yield of maize. In H. D. Loden \& D. Wilkinson (Eds.), Proceedings of Annual Corn and sorghum International Research Conference (pp. 43-73). American Seed Trade Association, Washington, United States of America.

Drouet, J. L., \& Kiniry, J. R. (2008). Does spatial arrangement of 3D plants affect light transmission and extinction coefficient within maize crops? Field Crops Res., 107, 62-69. http://dx.doi.org/10.1016/j.fcr.2007.12.015

Fanadzo, M., Chiduza, C., \& Mnkeni, P. N. S. (2010). Effect of inter-row spacing and plant population on weed dynamics and maize (Zea mays L.) yield at Zanyokwe irrigation scheme, Eastern Cape, South Africa. Afri. J. Agric. Res., 5, 518-523.

Girardin, P. H., \& Tollenaar, M. (1994). Effects of intra-specific interference on maize leaf azimuth. Crop Sci., 34, 151-155. http://dx.doi.org/10.2135/cropsci1994.0011183X003400010027x

Girma, K., Martin, K. L., Anderson, R. H., Arnall, D. B., Brixey, K. D., Casillas, M. A., ... Raun, W. R. (2006). Mid season prediction of wheat grain yield potential using plant soil and sensor measurements. J. Plant Nutri., 29, 873-897. http://dx.doi.org/10.1080/01904160600649187

Gomez, K. A., \& Gomez, A. A. (2010). Statistical Procedures for Agricultural Research (2nd ed., p. 680). John Wiley and Sons, New York, United States of America.

Gotz, S., \& Bernhardt, H. (2008). GPS controlled mechanism for precision maize seeding-field tested example for practical use. Retrieved from http://www.lwk-niedersachsen.de/ index.cfm/portal/6/nav

Islam, Z., Bachi, B., \& Hossain, M. (2007). Adoption of leaf color chart for nitrogen use efficiency in rice: Impact assessment of a farmer participatory experiment in West Bengal, India. Field Crops Res., 103, 70-75. http://dx.doi.org/10.1016/j.fcr.2007.04.012

Khosla, R., Westfall, R. M., Reich, R. M., Mahal, J. S., \& Gangloff, W. J. (2010). Spatial variation and site-specific management. In M. A. Oliver (Eds.), Geostatistical applications for precision agriculture (pp. 195-219). http://dx.doi.org/10.1007/978-90-481-9133-8_8

Maddonni, G. A., Chelle, M., Drouet, J. L., \& Andrieu, B. (2001a). Light interception of contrasting azimuth canopies under square and rectangular plant spatial distributions: Simulations and crop measurements. Field Crops Res., 70, 1-13. http://dx.doi.org/10.1016/S0378-4290(00)00144-1

Maddonni, G. A., Cirilo, A. G., \& Otegui, M. E. (2006). Row width and maize grain yield. Agron. J., 98, 1532-1543. http://dx.doi.org/10.2134/agronj2006.0038

Maddonni, G. A., Otegui, M. E., \& Cirilo, A. G. (2001b). Plant population density, row spacing and hybrid effects on maize canopy architecture and light attenuation. Field Crops Res., 7, 183-193. http://dx.doi.org/10.1016/S0378-4290(01)00158-7

Maddonni, G. A., Otegui, M. E., Andrieu, B., Chelle, M., \& Casal, J. J. (2002). Maize leaves turn away from neighbours. Plant Physiol., 130, 1181-1189. http://dx.doi.org/10.1104/pp.009738

Monsi, M., \& Saeki, T. (1953). Concerning the light factor in plant communities and its significance for drymatter production. Jap. J. Bot., 14, 22-52. 
Pasuquin, J. M., Saenong, S., Tan, P. S., Witt, C., \& Fisher, M. J. (2012). Evaluating N management strategies for hybrid maize in Southeast Asia. Field Crops Res., 134, 153-157. http://dx.doi.org/10.1016/j.fcr.2012.06.004

Rashid, A. J., Stark, C., Tanveer, A., \& Mustafa, T. (1999). Use of canopy temperature measurements as a screening tool for tolerance in spring wheat. J. Agron. Crop Sci., 182, 231-237. http://dx.doi.org/10.1046/j.1439-037x.1999.00335.x

Singh, S. S. (1997). Crop management under Irrigated and Rainfed Conditions (pp. 78-102). Kalyani Publishers, Ludhiana.

Witt, C., Pasuquin, J. M. C. A., Mutters, R., \& Buresh, R. J. (2005). New leaf color chart for effective nitrogen management in rice. Better Crops-Southeast Asia, 89, 36-39.

\section{Copyrights}

Copyright for this article is retained by the author(s), with first publication rights granted to the journal.

This is an open-access article distributed under the terms and conditions of the Creative Commons Attribution license (http://creativecommons.org/licenses/by/3.0/). 